\section{A era da terapia celular}

Milton A. Ruiz

Até recentemente, a terapia com células-tronco hemopoéticas $(\mathrm{CTH})$ era restrita ao tratamento de doenças hematológicas, onco-hematológicas e a pacientes graves com doenças hereditárias e auto-imunes sem opções de cura.

Com os novos conhecimentos sobre a plasticidade das $\mathrm{CTH}$ e de experimentos que comprovaram a transdiferenciação e a desdiferenciação, entidades não-hematológicas passaram a ser alvo para o emprego da terapia celular. ${ }^{1,2}$

$\mathrm{O}$ apelo mundial para pesquisas com $\mathrm{CT}$ embrionárias pressionou governos e, recentemente, o Congresso Brasileiro legislou sobre o tema. O Ministério de Ciências e Tecnologia e o da Saúde do Brasil há poucos meses também abriram linhas de crédito para pesquisas na área de cardiologia e acena para ensaios clínicos e pré-clínicos para doenças incuráveis.

No bojo destas questões encontram-se os pacientes, ávidos de serem tratados, as mídias à procura de informações divulgando e alardeando as células da esperança como terapêutica do futuro. Neste ponto creio ser necessária uma ponderação e observação, visto que a terapia com célulastronco, menos em doenças hematológicas e onco-hematológicas, ainda é experimental com resultados discutíveis e não comprovados cientificamente.

Fora algumas aparições de elementos da área na mídia, existe uma ausência de profissionais mais habituados com a terapia em todo o processo atual de discussão, fato este observado inclusive no projeto governamental do Estudo Multicêntrico Randomizado de Terapia Celular em Cardiologia, ${ }^{3}$ em que a participação de hematologistas é inexpressiva. Na configuração do estudo, participação de 40 instituições governamentais, não governamentais e privadas, duplo cego e randomizado com 1.200 pacientes, no período de 18 meses, distribuídos em quatro braços - Cardiomiopatia dilatada, Cardiomiopatia chagásica, Infarto agudo do miocárdio e Doença isquêmica crônica - se avaliará a segurança do procedimento e dados objetivos de melhora dos parâmetros cardiológicos e da qualidade de vida da casuística. $\mathrm{Na}$ organização do documento consensual de procedimentos hematológicos do estudo, como coleta, preparo, preservação, seleção, administração de CTH, foi definido ser necessária a presença de hematologista afeito à área de TMO para desempenho das funções descritas e assessoramento dos grupos envolvidos no estudo.

Considero tal decisão, determinada pela coordenação do projeto, alvissareira para a hematologia, que deve observar os resultados, participar dos estudos de terapia celular nas áreas não-hematológicas, e, com estes ensinamentos, obter um feed back para o tratamento dos doentes hematológicos.

\section{Referências bibliográficas}

1. Grove E, Bruscia E, Krause DS., Plasticity of bone marrow-derived stem cells. Stem cells. 2004; 22 (4): 487- 500.

2. Graf T, Diferentiation plasticity of hematopoietic cells. Blood. 2002; 99 (9):3089-3101.

3. Estudo Multicêntrico Randomizado de Terapia Celular em Cardiologia (EMRTCC) - Ministério da Saúde - Brasil, 2004.

Professor, Livre-docente de Hematologia da Faculdade de Medicina de São José do Rio Preto, SP - Brasil.

Coordenador da Unidade de TMO do Hospital de Base de São José do Rio Preto, Cintrans-Funfarme-Famerp, SP-Brasil. Coordenador do Grupo de Estudos de Terapia Celular em Cardiologia do IMC de São José do Rio Preto, SP - Brasil

Correspondência para: Milton Artur Ruiz

Avenida Brigadeiro Faria Lima 5544

15090-000 - SJ Rio Preto-SP

Tel.: 17 3201-5172

E-mailmilruiz@yahoo.com.br 